Canadian Metallurgical Quarterly, Vol 44, No 3 pp 00-00, 2005 (c) Canadian Institute of Mining, Metallurgy and Petroleum Published by Canadian Institute of Mining, Metallurgy and Petroleum Printed in Canada. All rights reserved

\title{
THERMODYNAMIC MODELLING OF THE Mg-Al-Ca SYSTEM
}

\author{
F. ISLAM and M. MEDRAJ \\ Department of Mechanical and Industrial Engineering \\ Concordia University, Montreal, Quebec, Canada
}

(Received in revised form April, 2005)

\begin{abstract}
In this study, the ternary Mg-Al-Ca phase diagram was constructed by combining the three constituent binary systems of $\mathrm{Mg}-\mathrm{Al}, \mathrm{Al}-\mathrm{Ca}$ and $\mathrm{Mg}-\mathrm{Ca}$. The $\mathrm{Mg}-\mathrm{Al}$ system is taken from COST 507 database. The thermodynamic descriptions of the $\mathrm{Mg}-\mathrm{Ca}$ and $\mathrm{Al}-\mathrm{Ca}$ systems are obtained by modelling the Gibbs energy of all phases as a function of composition and temperature. The model parameters were optimized by minimizing Gibbs energy considering phase equilibria and thermodynamic data available in the literature. A self-consistent thermodynamic database was constructed with the optimized parameters of the three subsystems. The binary phase diagrams, their thermodynamic properties, the ternary phase diagram and the critical points were calculated from this database and compared with experimental results from the literature.

Résumé - Dans cette étude, on a construit le diagramme de phase ternaire Mg-Al-Ca en combinant les trois systèmes binaires constituants de $\mathrm{Mg}-\mathrm{Al}, \mathrm{Al}-\mathrm{Ca}$ et $\mathrm{Mg}$-Ca. Le système $\mathrm{Mg}$ - $\mathrm{Al}$ provient de la base de données COST 507. On a obtenu les descriptions thermodynamiques des systèmes $\mathrm{Mg}-\mathrm{Ca}$ et $\mathrm{Al}-\mathrm{Ca}$ en modélisant l'énergie de Gibbs de toutes les phases en fonction de la composition et de la température. On a optimisé les paramètres du modèle en minimisant l'énergie de Gibbs, en considérant les équilibres de phase et les données thermodynamiques disponibles dans la littérature. On a construit une base de données thermodynamiques auto-consistantes avec les paramètres optimisés des trois sous-systèmes. On a calculé les diagrammes de phase binaires, leurs propriétés thermodynamiques, le diagramme de phase ternaire et les points critiques à partir de cette base de données et on les a comparés aux résultats expérimentaux de la littérature.
\end{abstract}

\section{INTRODUCTION}

Mg alloys have drawn attention for their application in automobile and aerospace industries due to their light weight compared to $\mathrm{Al}$ and $\mathrm{Fe}$. In spite of this promising property, the application of $\mathrm{Mg}$ is still behind that of competing materials such as aluminum and plastics due to its low rigidity, corrosion resistance and yield strength. Therefore, attempts have been made to improve the characteristics of magnesium alloys by employing different alloying elements $[1,2]$. Aluminum is the most important alloying element for magnesium to enhance mechanical and corrosion properties and for better castability. However, the use of $\mathrm{Mg}-\mathrm{Al}$ alloys is limited to low temperature applications because of their low creep resistance due to the presence of the $\gamma$-phase $\left(\mathrm{Mg}_{17} \mathrm{Al}_{12}\right)$ at the grain boundaries in the as-cast condition. The $\gamma$-phase is incoherent with the $\alpha-\mathrm{Mg}$ matrix and exists at a wide composition range of 48 to $52 \mathrm{wt} \% \mathrm{Al}$ and has a low melting point of 710 $\mathrm{K}$. The compound is therefore prone to ageing, has poor metallurgical stability as the temperature is increased and may contribute to the poor creep resistance [3].
The addition of rare earth metals ( $\mathrm{Y}, \mathrm{Ce}$ and $\mathrm{Nd}$ ) to $\mathrm{Mg}$ $\mathrm{Al}$ alloys can improve the creep resistance, but they are too expensive to use in the mass automotive industry. Some attempts were made to replace rare earth metals with $\mathrm{Ca}$. It has been found that $\mathrm{Mg}$-Al-Ca based alloys have equal or better creep and corrosion resistance than those of the AE42 series. The increased creep resistance of $\mathrm{Mg}-\mathrm{Al}-\mathrm{Ca}$ alloys is due to the presence of a thermally stable $\mathrm{Al}_{2} \mathrm{Ca}$ intermetallic compound along the grain boundary in the as-cast structure. It provides effective pinning to resist grain boundary sliding and improve creep resistance. Moreover, complete elimination of the $\gamma$-phase is possible by keeping the ratio of $\mathrm{Al}$ and $\mathrm{Ca}$ content at less than 2 [3-5]. Mg-Al-Ca based alloys meet the requirements for critical components in the automobile industry where higher creep and corrosion resistance at an elevated temperature are required. Despite the fulfillment of the required properties for use at an elevated temperature, the complete phase diagram of $\mathrm{Mg}$-Al-Ca system with all critical points is scarcely known. Construction of an $\mathrm{Mg}$-Al-Ca phase diagram is necessary for the development of new alloys and a better understanding of their behaviour. 


\section{THERMODYNAMIC MODELLING}

The calculation of the phase diagram using thermodynamic modelling reduces the effort required to determine the equilibrium conditions of a multicomponent system and focuses the experimental work on a critical region. Equilibrium is best described in terms of Gibbs free energy (G). A system at constant temperature and pressure will approach an equilibrium state that minimizes $\mathrm{G}$. For $\mathrm{Mg}-\mathrm{Ca}$ and $\mathrm{Al}-\mathrm{Ca}$ systems, phase diagrams and thermodynamic data were critically assessed for all phases from room temperature to above the liquidus temperatures at atmospheric pressure. All these data were optimized to obtain a set of model parameters for Gibbs energy of the liquid and all solid phases as a function of composition and temperature. Values of the standard Gibbs energies $\left(\mathrm{G}^{\circ}\right)$ of each component are stored in the database along with optimized parameters which define the Gibbs energy of mixing according to the Redlich-Kister polynomial model and Gibbs free energy of the formation of stoichiometric compounds. Thermodynamic models for different phases are described in the following sections.

\section{Unary Phases}

The Gibbs energy of the pure element, $i$, with a certain phase, $\phi$, is described as a function of temperature by

$$
\begin{aligned}
{ }^{0} G_{i}^{\phi}(T) & =G_{i}^{\phi}(T)-H_{i}^{S E R} \\
{ }^{0} G_{i}^{\phi}(T) & =a+b T+c T \ln T+d T^{2} \\
& +e T^{3}+f T^{-1}+g T^{7}+h T^{-9}
\end{aligned}
$$

where $H_{i}^{S E R}$ (the molar enthalpy of the stable element reference (SER)) is at $298.15 \mathrm{~K}$ and $1 \mathrm{bar}$, and $\mathrm{T}$ is the absolute temperature. The values of the coefficients $a$ to $h$ are taken from the Scientific Group Thermodata Europe (SGTE) compilation by Dinsdale [6].

\section{Disordered Solution Phases}

The Gibbs energy of a disordered solution phase is described by

$$
\begin{aligned}
G= & x_{i}{ }^{0} G_{i}^{\phi}+x_{j}{ }^{0} G_{j}{ }^{\phi} \\
& +R T\left[x_{i} \ln x_{i}+x_{j} \ln x_{j}\right]+{ }^{e x} G^{\phi}
\end{aligned}
$$

where $\phi$ denotes the phase in question and $x_{i}$ and $x_{j}$ denote the mole fraction of component $i$ and $j$, respectively. The first two terms on the right hand side of Equation 2 represent the Gibbs energy of the mechanical mixture of the components, the third term is the ideal Gibbs energy of mixing and the fourth term is the excess Gibbs energy. The excess Gibbs energy is represented using the Redlich-Kister equation

$$
{ }^{e x} G^{\phi}=x_{i} \cdot x_{j} \sum_{n=0}^{n=m}{ }^{n} L_{i, j}^{\phi}\left(x_{i}-x_{j}\right)^{n}
$$

$$
\text { with }{ }^{n} L_{i, j}^{\phi}=a_{n}+b_{n} T \quad(n=0, \ldots m)
$$

where $a_{n}$ and $b_{n}$ are model parameters to be optimized in terms of experimental and thermodynamic data.

\section{Stoichiometric Phases}

The Gibbs energy for stoichiometric compounds is described by

$$
G^{\phi}=x_{i}^{0} G_{i}^{\phi_{1}}+x_{j}^{0} G_{j}^{\phi_{2}}+\Delta G_{f}
$$

with $\Delta G_{f}=a+b \times T$

where $x_{i}$ and $x_{j}$ are the mole fraction of component $i$ and $j$, respectively and ${ }^{0} G_{i}^{\phi_{1}}$ represents the Gibbs energy of a component in its standard state. However, the Gibbs energy of the compound phase may refer to different crystal structures from those of the pure elements, $\phi_{1}$ and $\phi_{2} . \Delta \mathrm{G}_{\mathrm{f}}$ is the Gibbs energy of formation per mole of atoms of the stoichiometric compound; the parameters $a$ and $b$ are obtained by optimization phase equilibria and thermodynamic data. In this work, the computer program WinPhaD [7] was used for optimizing the binary subsystems ( $\mathrm{Mg}-\mathrm{Ca}$ and $\mathrm{Al}-\mathrm{Ca})$, whereas the calculation of the Mg-Al-Ca ternary was done using FactSage [8] software.

\section{Mg-Ca SYSTEM}

\section{Phase Diagram}

First Baar [9] determined the complete liquidus temperatures for the Mg-Ca system. In his work, the purity of the starting elements was low and there was significant loss of Ca during alloying. Paris [10] also determined the complete liquidus temperature but he did not mention the purity of the materials. Haughton [11] determined the liquidus temperature of the $\mathrm{Mg}$-rich side in the composition range of 0 to $17 \% \mathrm{Ca}$ rigorously avoiding loss of Ca. On the other hand, Vosskühler [12] analyzed $\mathrm{Mg}$-rich alloys up to $47.65 \% \mathrm{Ca}$. The measurement of the liquidus temperature by Klemm and Dinkelacker [13] agrees fairly well with both of [11] and [12]. Nayeb-Hashemi and Clark [14] critically evaluated this system. Agarwal et al. [15] measured calorimetrically the enthalpies of the mixing of liquid Ca-Mg alloy at $1023 \mathrm{~K}$ and the heat contents of $\mathrm{Mg}_{2} \mathrm{Ca}$ between 750 and $1150 \mathrm{~K}$. They reoptimized the system with these experimental and literature data to verify the compatibility of the results available from different sources. According to their calculation, the stable phases in the $\mathrm{Mg}-\mathrm{Ca}$ system are the liquid, the $(\mathrm{Mg})$ solid solution, the $\mathrm{Ca}-\mathrm{bcc}$, the $\mathrm{Ca}-\mathrm{fcc}$ and the congruent intermetallic compound $\mathrm{Mg}_{2} \mathrm{Ca}$ which divides the phase diagram into two eutectic systems. $\mathrm{Mg}_{2} \mathrm{Ca}$ is reported in the literature as a line compound $[14,15]$. Several researchers measured the solubility of $\mathrm{Ca}$ in 
$\operatorname{Mg}[11,12,16]$. Among them, Vosskühler [12] and Burke [16] reported limited solubility and their results agree fairly well, whereas other researchers reported larger solubility. Hence the limited solubility will be considered in this work.

\section{Thermodynamic Properties}

The standard enthalpy of formation of the compound $\mathrm{Mg}_{2} \mathrm{Ca}$ measured by King and Kleepaa [17] using tin solution calorimetry is $-40.50 \pm 1.25 \mathrm{~kJ} / \mathrm{mol}$ at $298 \mathrm{~K}$. Davison and Smith [18] also measured the enthalpy of formation at room temperature as $-39.38 \pm 2.63 \mathrm{~kJ} / \mathrm{mol}$ by acid solution calorimetry and mentioned that the heat of formation determined by King and Kleepaa [17] is "the most precise and probably the most reliable." Sommer et al. [19] measured the heat of mixing $\left(\Delta \mathrm{H}_{\text {mix }}\right)$ of liquid $\mathrm{Mg}$-Ca by high temperature calorimetry. Although Agarwal et al. [15] also measured the enthalpy of mixing calorimetrically at $1023 \mathrm{~K}$, their results were not considered in this study because they contradicted those of Sommer et al. [19]. Hultgren et al. [20] and Sommer [21] determined the activity of $\mathrm{Mg}$ and $\mathrm{Ca}$ by vapour pressure measurement at $1010 \mathrm{~K}$ and $1200 \mathrm{~K}$, respectively. Mishra et al. [22] calculated the activity of $\mathrm{Mg}$ and $\mathrm{Ca}$ at $1200 \mathrm{~K}$. Mashovets [23] also determined the activity of $\mathrm{Mg}$ and $\mathrm{Ca}$ in liquid at $1073 \mathrm{~K}$ by vapour pressure measurement using the gas carrier technique. The activity of $\mathrm{Ca}$ reported by Mashovets [23] showed positive deviation from ideal solution, whereas Sommer [21] showed negative deviation. As for the regular solution, with $\Delta \mathrm{H}_{\text {mix }}<0$, activity is less than that of the ideal solution; the thermodynamic activities calculated from the primary results of the measurements given by Sommer [21] seem to be more reliable. Moreover, they are more recent and consistent with other works; hence, they will be used for the optimization of the $\mathrm{Mg}$-Ca system.

\section{Optimization of Phase Diagram and Thermodynamic Properties}

Phase Diagram: The model calculated phase diagram of the $\mathrm{Mg}-\mathrm{Ca}$ system in relation to calculated and experimental results from the literature is shown in Figure 1.

It can be seen from Figure 1 that there is a good agreement between experimental and calculated results. This indicates that the thermodynamic model is capable of reproducing the measured phase diagram within experimental error limits. The optimized model parameters are given in Table 1. Three Redlich-Kister interaction parameters were required to

Table I - Parameters for the liquid phase, $\mathrm{Mg}_{2} \mathrm{Ca}$ stoichiometric phase of the Mg-Ca system

\begin{tabular}{cccc}
\hline Phase & Terms & $\mathrm{a}(\mathrm{J} /$ mol-atom $)$ & $\mathrm{b}(\mathrm{J} /$ mol-atom.K $)$ \\
\hline & $\mathrm{L}_{0}$ & -24018.60 & 1.9432 \\
Liquid & $\mathrm{L}_{1}$ & 1785.73 & 4.4724 \\
& $\mathrm{~L}_{2}$ & 14387.50 & -22.9827 \\
Mg-hcp & $\mathrm{L}_{0}$ & 7150.90 & -9.4012 \\
$\mathrm{Mg}_{2} \mathrm{Ca}$ & $\Delta \mathrm{G}_{\mathrm{f}}$ & -12704.40 & 1.8093 \\
\hline
\end{tabular}

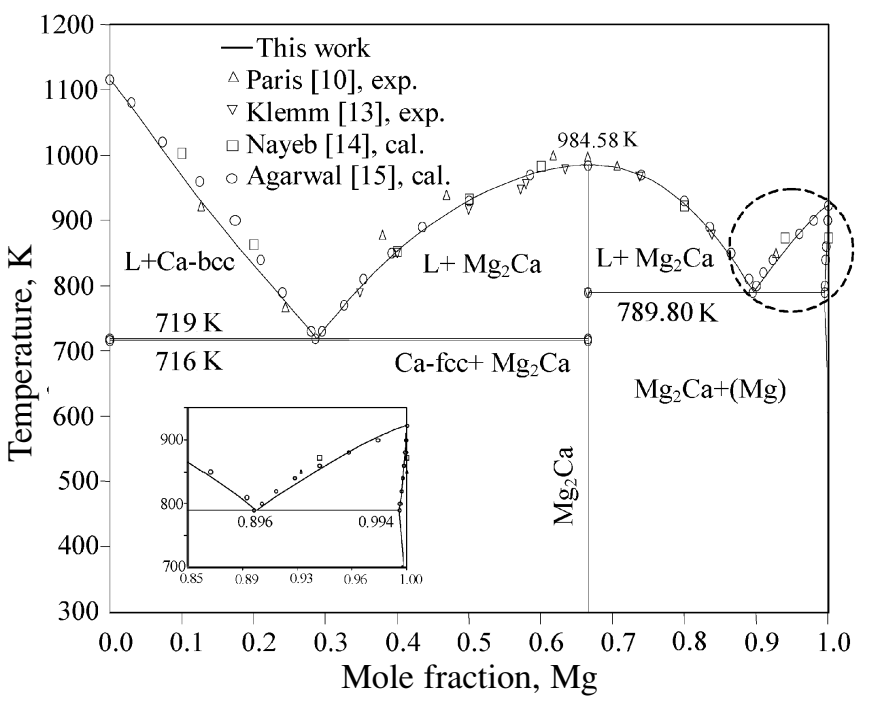

Fig. 1. Optimized Mg-Ca with data from the literature (cal.: calculated, exp.: experimental).

model the liquid phase and two parameters were optimized for the Gibbs energy of formation of the stoichiometric compound. The reference states of the Gibbs energy of formation of $\mathrm{Mg}_{2} \mathrm{Ca}$ were considered as $\mathrm{Mg}$ - hexagonal close packed (hcp) and Ca- face centred cublic (fcc). No lattice stability values were added to the pure components.

A comparison between calculated and experimental results of the critical regions of $\mathrm{Mg}$-Ca phase diagram is presented in Table II.

There is a small solid solubility range of $\mathrm{Ca}$ in $\mathrm{Mg}$. An almost straight line originating from the melting point of $\mathrm{Mg}$ and terminating at $99.44 \mathrm{~mol} \% \mathrm{Mg}$ at $789.80 \mathrm{~K}$, shown in Figure 1, represents the $(\mathrm{Mg})$ solidus. This agrees with the results of Nayeb-Hashemi and Clark [14] (99.18 mol\% Mg at $789.5 \mathrm{~K})$ and Agarwal et al. [15] (99.50 mol\% $\mathrm{Mg}$ at $790 \mathrm{~K}$.)

Thermodynamic Properties: The data for the enthalpy of mixing measured by Sommer et al. [19] at $1150 \mathrm{~K}$ was used in the optimization and show very good agreement with the model calculated values shown in Figure 2.

The activities of $\mathrm{Mg}$ and $\mathrm{Ca}$ in $\mathrm{Mg}$-Ca liquid at $1010 \mathrm{~K}$ are shown in Figure 3. It can be seen from this figure that the calculated $\mathrm{Mg}$ activity agrees with the experimental results of $[14,20,22,23]$. The activity of $\mathrm{Ca}$ agrees with Sommer [21]. However, the values reported by Hultgren et al. [20] and Mishra et al. [22] are higher than those of Sommer [21]. This is probably due to the fact that they obtained their results at significantly different temperatures. Sommer [21] measured activities of $\mathrm{Ca}$ only for $\mathrm{Ca}$-rich alloys. Later he calculated the activities of $\mathrm{Ca}$ for alloys across the phase diagram from those of $\mathrm{Mg}$ using the Gibbs-Duhem equation.

Figure 4 shows that calculated partial Gibbs free energies of $\mathrm{Mg}$ and $\mathrm{Ca}$ in $\mathrm{Mg}-\mathrm{Ca}$ liquid at $1100 \mathrm{~K}$ follow the trend of the experimental data from the literature. Figure 5 shows the calculated partial enthalpy of the mixing of $\mathrm{Ca}$ in $\mathrm{Mg}-\mathrm{Ca}$ 
Table II - Comparison between calculated and experimental values of critical regions in the Mg-Ca system

\begin{tabular}{|c|c|c|c|c|}
\hline Reaction & $\begin{array}{l}\text { Reaction } \\
\text { type }\end{array}$ & Temp, K & $\begin{array}{c}\mathrm{Mg} \\
\mathrm{mol} \%\end{array}$ & References \\
\hline \multirow{4}{*}{$\mathrm{L} \leftrightarrow \mathrm{Mg}-\mathrm{hcp}$} & \multirow{4}{*}{ Melting } & 878.00 & 100.00 & [14] \\
\hline & & 923.00 & 100.00 & {$[15]$} \\
\hline & & 998.00 & - & [10] \\
\hline & & 923.00 & 100.00 & This work \\
\hline \multirow{3}{*}{$\mathrm{L} \leftrightarrow \mathrm{Ca}-\mathrm{bcc}$} & \multirow{3}{*}{ Melting } & $1,115.00$ & 0.00 & [14] \\
\hline & & $1,115.00$ & 0.00 & [15] \\
\hline & & $1,115.00$ & 0.00 & This work \\
\hline \multirow{3}{*}{$\mathrm{L} \leftrightarrow \mathrm{Mg}_{2} \mathrm{Ca}$} & \multirow{3}{*}{ Congruent } & 988.00 & 66.00 & [14] \\
\hline & & 984.00 & 66.00 & [15] \\
\hline & & 984.58 & 66.00 & This work \\
\hline \multirow{3}{*}{$\mathrm{Ca}-\mathrm{fcc} \leftrightarrow \mathrm{Ca}-\mathrm{bcc}$} & \multirow{3}{*}{ Allotropic } & 716.00 & 0.00 & [14] \\
\hline & & 716.00 & 0.00 & [15] \\
\hline & & 716.00 & 0.00 & This work \\
\hline \multirow{5}{*}{$\mathrm{L} \leftrightarrow \mathrm{Mg}_{2} \mathrm{Ca}+\mathrm{Ca}-\mathrm{fcc}$} & \multirow{5}{*}{ Eutectic } & 718.00 & 27.00 & [14] \\
\hline & & 719.00 & 28.60 & [15] \\
\hline & & 733.00 & 26.60 & [10] \\
\hline & & 718.00 & 27.0 & [13] \\
\hline & & 719.00 & 28.83 & This work \\
\hline \multirow{4}{*}{$\mathrm{L} \leftrightarrow \mathrm{Mg}_{2} \mathrm{Ca}+\mathrm{Mg}-\mathrm{hcp}$} & \multirow{4}{*}{ Eutectic } & 789.50 & 89.50 & [14] \\
\hline & & 790.00 & 89.50 & [15] \\
\hline & & 798.00 & 88.60 & [10] \\
\hline & & 789.80 & 89.61 & This work \\
\hline
\end{tabular}

liquid at $1032 \mathrm{~K}$ compared with experimental results from Agarwal et al. [15]. Although these data were predicted, that is why they were not included in the optimization, they agree well with the results calculated from the thermodynamic model. This provides strong evidence of the quality of the model.

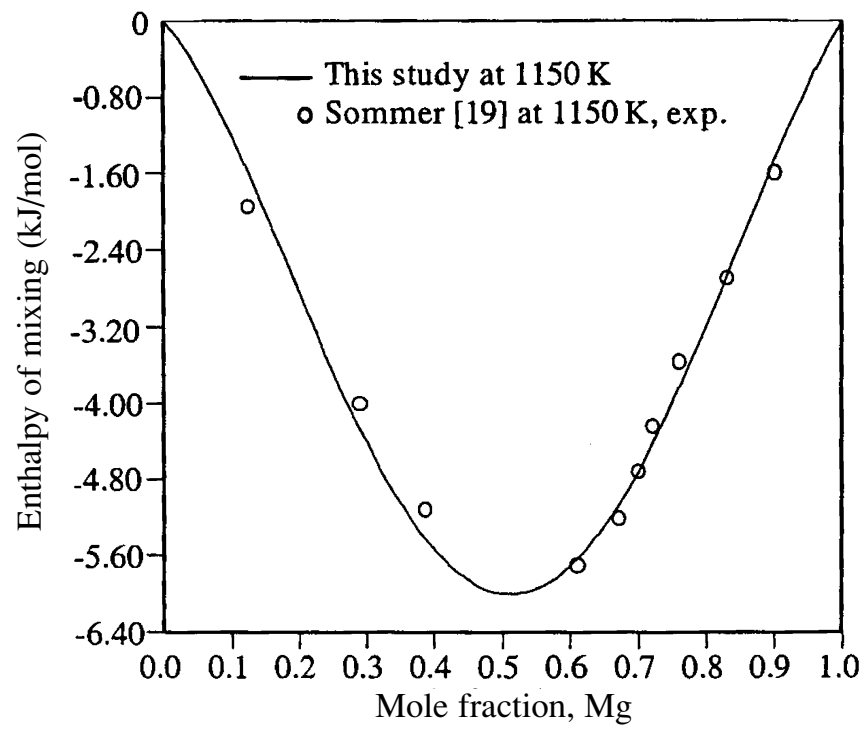

Fig. 2. Enthalpy of mixing Mg-Ca liquid at $1150 \mathrm{~K}$ (exp.: experimental).
In this study the calculated enthalpy of formation of $\mathrm{Mg}_{2} \mathrm{Ca}$ intermetallic compound is $-12.70 \mathrm{~kJ} / \mathrm{g}$-atom at $298 \mathrm{~K}$ which is in close agreement with the values proposed by Davison and Smith [18] and King and Kleepaa [17] as -13.17 $\mathrm{kJ} / \mathrm{g}$-atom and $-13.5 \mathrm{~kJ} / \mathrm{g}$-atom, respectively.

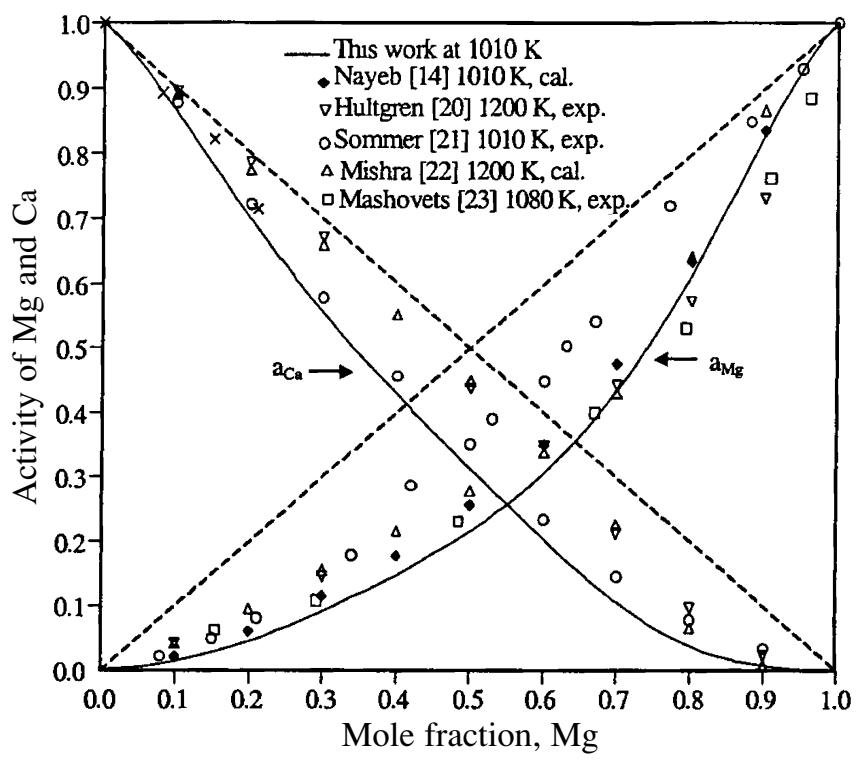

Fig. 3. Activity of $\mathrm{Mg}$ and $\mathrm{Ca}$ in $\mathrm{Mg}-\mathrm{Ca}$ liquid. 


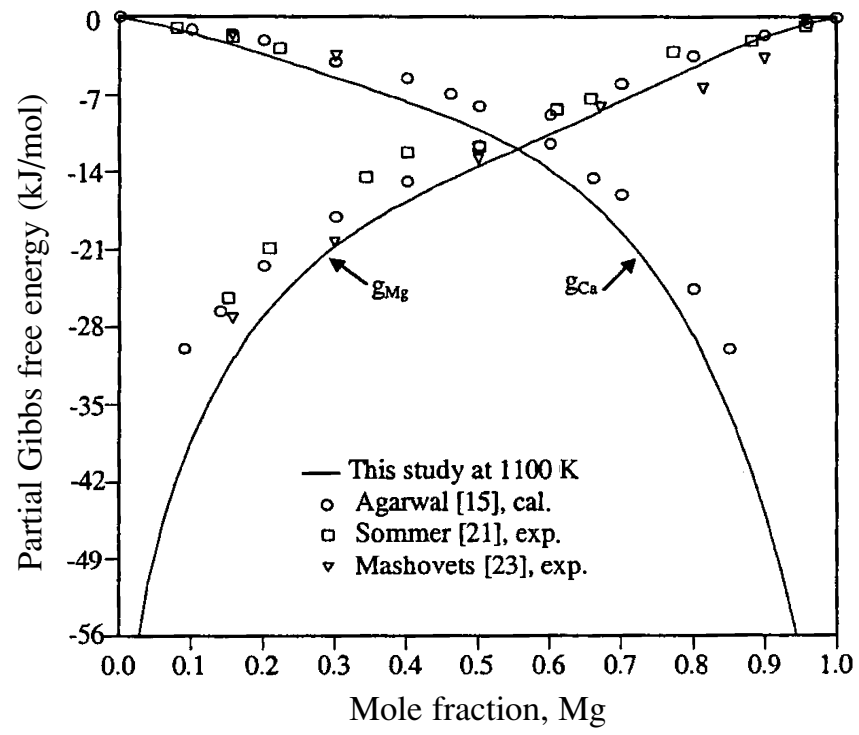

Fig. 4. Partial Gibbs energy of $\mathrm{Mg}$ and $\mathrm{Ca}$ in $\mathrm{Mg}$-Ca liquid.

\section{Al-Ca SYSTEM}

\section{Phase Diagram}

Matsuyama et al. [24] investigated the Al-Ca system thoroughly by thermal and thermoresistometric analysis and microscopic examination. They reported two intermetallic compounds: $\mathrm{Al}_{2} \mathrm{Ca}$ which melts congruently at $1352 \mathrm{~K}$ and $\mathrm{Al}_{4} \mathrm{Ca}$ which melts incongruently at $973 \mathrm{~K}$ [24]. In the Al-Ca system, most experimental investigations deal mainly with the Al-rich corner which is technically interesting for aluminum alloys. Consequently, only limited experimental work for the Ca-rich part was reported. Recently, Kevorkov and Schmid-Fetzer [25] investigated the Al-Ca system experimentally and determined the complete phase diagram. They reported two new intermetallic compounds in the $\mathrm{Ca}$ rich region $\mathrm{AlCa}$ and $\mathrm{Al}_{3} \mathrm{Ca}_{8}$. Later, Kevorkov et al. [26] optimized this system and determined the thermodynamic properties. They did not report the crystal structure of AlCa because of the slow formation kinetics of this phase during the peritectic reaction from the very stable $\mathrm{Al}_{2} \mathrm{Ca}$ phase that prevented the preparation of a single phase sample for the crystallographic investigation. Huang and Corbett [27] reported the occurrence of $\mathrm{Al}_{14} \mathrm{Ca}_{13}$ compound with monoclinic structure instead of $\mathrm{AlCa}$. From the most recent publications [26-28], it can be concluded that the stable phases in this system are: the liquid, $\mathrm{Al}-\mathrm{fcc}, \mathrm{Ca}-\mathrm{bcc}, \mathrm{Ca}-\mathrm{fcc}$ and the four intermetallic compounds $\mathrm{Al}_{4} \mathrm{Ca}, \mathrm{Al}_{2} \mathrm{Ca}, \mathrm{Al}_{14} \mathrm{Ca}_{13}$ and $\mathrm{Al}_{3} \mathrm{Ca}_{8}$. Later, Ozturk et al. [28] used both associate and random solution models to reoptimize the system with $\mathrm{Al}_{14} \mathrm{Ca}_{13}$ intermetallic compound instead of AlCa. Itkin et al. [29] mentioned that the solubility of $\mathrm{Ca}$ at $873 \mathrm{~K}$ was found to be less than 0.03 at\% which contradicts the recent investigation by Kevorkov and Schmid-Fetzer [25]. During X-ray diffraction

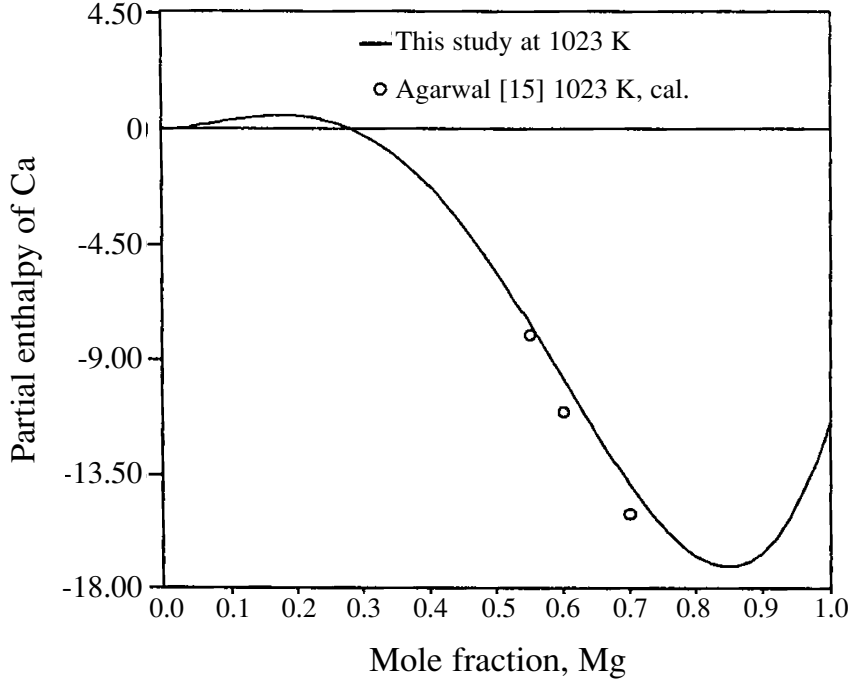

Fig. 5. Partial enthalpy of $\mathrm{Ca}$ in $\mathrm{Mg}$-Ca liquid (cal.: calculated).

(XRD) investigation of the $\mathrm{Al}$ and $\mathrm{Ca}$-rich alloys, they found no deviation from the theoretical powder patterns, therefore, the mutual solubility between $\mathrm{Ca}$ and $\mathrm{Al}$ is considered negligible.

\section{Thermodynamic Properties}

Sommer et al. [30] used high temperature calorimetry to determine the enthalpy of the mixing of liquid Al-Ca at temperatures ranging between 1125 and $1190 \mathrm{~K}$. Their experimental results are in good agreement with the results of Notin et al. [31]. Ozturk et al. [28] compared the calculated enthalpy of mixing data in the liquid phase at $1453 \mathrm{~K}$ with Sommer et al. [30] and Notin et al. [31]. There is a trend that the minimum of the curve is shifted towards the $\mathrm{Al}$ side where the most stable intermetallic compound $\mathrm{Al}_{2} \mathrm{Ca}$ is formed. This indicates strong interactions between the atoms in the liquid at a composition around that of the $\mathrm{Al}_{2} \mathrm{Ca}$ compound. Kevorkov et al. [26] mentioned that they considered activities and the integral enthalpy of mixing data from the literature to optimize the thermodynamic parameters of the liquid phase. In order to adjust the liquid phase equilibria to experimental values, their calculated enthalpy of mixing had to deviate from the values reported in the literature [26]. Jacob et al. [32] determined the thermodynamic activities at $1373 \mathrm{~K}$ for liquid Al-Ca alloys using the Kundsen effusion method for the composition range of 0 to 38 at $\% \mathrm{Ca}$ and the distribution method for the composition range of 44 to 100 at\% $\mathrm{Ca}$. Schürmann et al. [33] calculated the activities of $\mathrm{Ca}$ in the liquid alloys using the boiling point determination technique. Kevorkov et al. [26] calculated the activity coefficient of $\mathrm{Ca}$ which agrees fairly well with [33] and shows reasonable agreement with [32]. Ozturk et al. [28] calculated the activity of $\mathrm{Ca}$ at $1600 \mathrm{~K}$ and compared it with both [32] and [33]. 
Several researchers measured the enthalpy of the formation of $\mathrm{Al}_{2} \mathrm{Ca}$ and $\mathrm{Al}_{4} \mathrm{Ca}$ compounds. Notin et al. [31] determined the enthalpy of the formation of these compounds at 953 and $1038 \mathrm{~K}$ experimentally. There is a reasonable agreement with the values of the enthalpy of formation for $\mathrm{Al}_{2} \mathrm{Ca}$ between Kevorkov et al. [26] and Notin et al. [31]. The small difference between them may be due to the difference in heat capacity $\Delta \mathrm{C}_{\mathrm{p}}$ of the formation reaction between room temperature and $1038 \mathrm{~K}$ [26]. For the $\mathrm{Al}_{14} \mathrm{Ca}_{13}$ intermetallic compound, there is no experimental enthalpy of formation data reported in the current literature up to date due to the sluggish formation kinetics of the phase and thus the difficulty of preparing an $\mathrm{Al}_{14} \mathrm{Ca}_{13}$-rich sample [28]. The enthalpy of the formation of $\mathrm{Al}_{3} \mathrm{Ca}_{8}$ stoichiometric phase was determined by Kevorkov et al. [26] by drop solution calorimetry. During the optimization of the Al-Ca system, Al-fcc and Ca-fcc are considered as the reference states for the Gibbs energy of formation for the four intermetallic compounds $\left(\mathrm{Al}_{4} \mathrm{Ca}, \mathrm{Al}_{2} \mathrm{Ca}\right.$, $\mathrm{Al}_{14} \mathrm{Ca}_{13}$ and $\left.\mathrm{Al}_{3} \mathrm{Ca}_{8}\right)$.

\section{Optimization of Phase Diagram and Thermodynamic Properties}

Phase Diagram: The model calculated phase diagram of the $\mathrm{Al}-\mathrm{Ca}$ system in relation to calculated and experimental results from the literature is shown in Figure 6.

It can be seen from Figure 6 that there is a good agreement between experimental and calculated results. However, the results of Matsuyama et al. [24] for the Al-rich side are not consistent with the current analysis. This is due to the fact that they considered $\mathrm{Al}_{4} \mathrm{Ca}$ and $\mathrm{Al}_{2} \mathrm{Ca}$ as the only intermediate compounds in this system.

The optimized model parameters are given in Table III. Four Redlich-Kister interaction parameters were required to model the liquid phase and two parameters were optimized for the Gibbs energy of formation of each stoichiometric compound. No lattice stability values were added to the pure components.

Comparison between the calculated and experimental results of the critical regions of Al-Ca phase diagram is shown in Table IV.

Thermodynamic Properties: The calculated enthalpy of the mixing of Al-Ca liquid in relation to the experimental results from the literature is presented in Figure 7. Although an

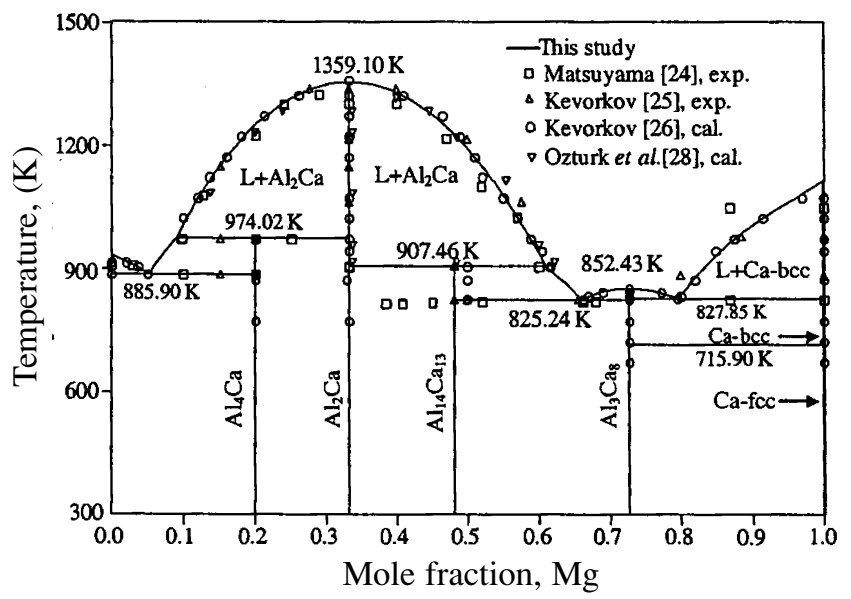

Fig. 6. Calculated Al-Ca phase diagram with data from the literature (cal.: calculated, exp.: experimental).

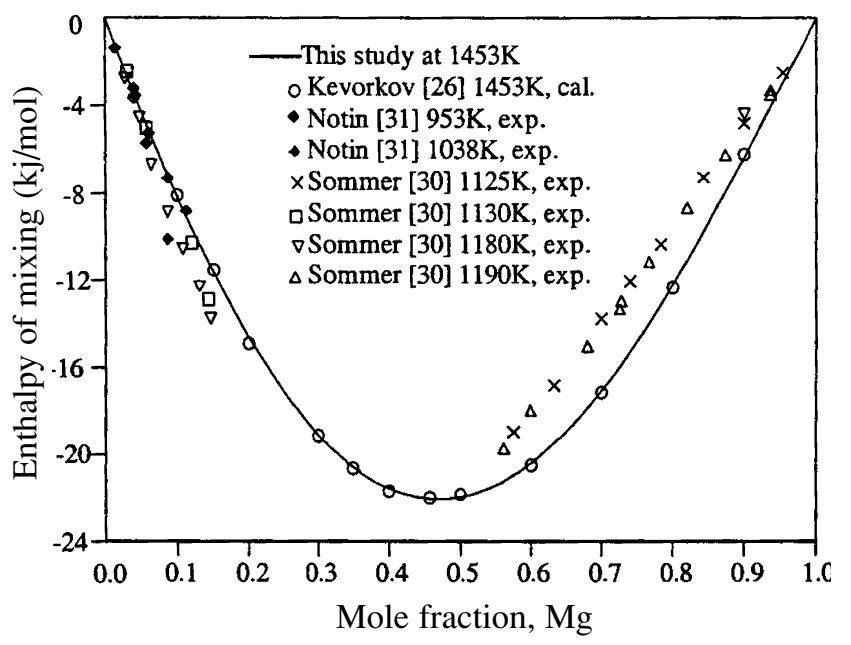

Fig. 7. Enthalpy of mixing of Al-Ca liquid at $1453 \mathrm{~K}$.

excellent agreement between this study and Kevorkov et al. [26] and Notin et al. [31] was obtained, Figure 7 shows that there is a reasonable agreement with Sommer et al. [30].

The calculated activity of $\mathrm{Ca}$ at $1373 \mathrm{~K}$ agrees very well with the results obtained by Ozturk et al. [28]. There is also a

Table III - The model parameters for the liquid phase and stoichiometric compounds of the Al-Ca system

\begin{tabular}{cccc}
\hline Phase & Terms & $\mathrm{a}(\mathrm{J} / \mathrm{mol}$-atom $)$ & $\mathrm{b}(\mathrm{J} / \mathrm{mol}$-atom.K) \\
\hline & $\mathrm{L}_{0}$ & -87894.60 & 29.8567 \\
Liquid & $\mathrm{L}_{1}$ & -12077.60 & 4.80628 \\
& $\mathrm{~L}_{2}$ & 11427.80 & -2.45047 \\
$\mathrm{Ll}_{3} \mathrm{Ca}$ & -1058.76 & -0.95372 \\
$\mathrm{Al}_{2} \mathrm{Ca}$ & $\Delta \mathrm{G}_{\mathrm{f}}$ & -17304.40 & 2.28098 \\
$\mathrm{Al}_{14} \mathrm{Ca}$ & $\Delta \mathrm{G}_{\mathrm{f}}$ & -29281.70 & 5.41175 \\
$\mathrm{Al}_{3} \mathrm{Ca}_{8}$ & $\Delta \mathrm{G}_{\mathrm{f}}$ & -26058.50 & 5.63473 \\
\hline
\end{tabular}


Table IV - Comparison between calculated and experimental values of critical regions in the Al-Ca system

\begin{tabular}{|c|c|c|c|c|}
\hline Reaction & Reaction type & Temp, K & $\begin{array}{l}\text { Mole \%, Ca } \\
\text { in liquid }\end{array}$ & References \\
\hline \multirow{3}{*}{$\mathrm{L} \leftrightarrow \mathrm{Al}-\mathrm{bcc}$} & \multirow{3}{*}{ Melting } & 933.00 & 0.00 & [26] \\
\hline & & 933.33 & 0.00 & [28] \\
\hline & & 933.45 & 0.00 & This work \\
\hline \multirow{3}{*}{$\mathrm{L} \leftrightarrow \mathrm{Ca}-\mathrm{bcc}$} & \multirow{3}{*}{ Melting } & $1,114.90$ & 100.00 & [26] \\
\hline & & $1,116.66$ & 100.00 & [28] \\
\hline & & $1,115.00$ & 100.00 & This work \\
\hline \multirow{3}{*}{ Ca-fcc $\leftrightarrow$ Ca-bcc } & \multirow{3}{*}{ Allotropic } & 715.9 & 100.00 & {$[26]$} \\
\hline & & 714.28 & 100.00 & [28] \\
\hline & & 715.90 & 100.00 & This work \\
\hline \multirow{5}{*}{$\mathrm{L} \leftrightarrow \mathrm{Al}_{4} \mathrm{Ca}+\mathrm{Al}-\mathrm{fcc}$} & \multirow{5}{*}{ Eutectic } & 889.00 & 5.20 & {$[24]$} \\
\hline & & 886.00 & - & [25] \\
\hline & & 886.00 & 5.10 & {$[26]$} \\
\hline & & 885.90 & 5.45 & [28] \\
\hline & & 885.90 & 5.20 & This work \\
\hline \multirow{4}{*}{$\mathrm{L} \leftrightarrow \mathrm{Al}_{14} \mathrm{Ca}_{13}+\mathrm{Al}_{3} \mathrm{Ca}_{8}$} & \multirow{4}{*}{ Eutectic } & 829.00 & - & {$[25]$} \\
\hline & & 825.10 & 66.20 & {$[26]$} \\
\hline & & 830.50 & 66.40 & [28] \\
\hline & & 825.24 & 65.97 & This work \\
\hline \multirow{4}{*}{$\mathrm{L} \leftrightarrow \mathrm{Al}_{14} \mathrm{Ca}_{13}+\mathrm{Ca}-\mathrm{bcc}$} & \multirow{4}{*}{ Eutectic } & 833.00 & - & [25] \\
\hline & & 827.50 & 79.50 & [26] \\
\hline & & 822.50 & 80.53 & [28] \\
\hline & & 827.85 & 79.69 & This work \\
\hline \multirow{5}{*}{$\mathrm{L}+\mathrm{Al}_{2} \mathrm{Ca} \leftrightarrow \mathrm{Al}_{4} \mathrm{Ca}$} & \multirow{5}{*}{ Peritectic } & 973.00 & 10.00 & {$[24]$} \\
\hline & & 973.00 & - & [25] \\
\hline & & 974.30 & 9.80 & [26] \\
\hline & & 974.00 & 9.89 & [28] \\
\hline & & 974.02 & 9.06 & This work \\
\hline \multirow{4}{*}{$\mathrm{L}+\mathrm{Al}_{2} \mathrm{Ca} \leftrightarrow \mathrm{Al}_{14} \mathrm{Ca}_{13}$} & \multirow{4}{*}{ Peritectic } & 906.00 & - & [25] \\
\hline & & 906.20 & 61.60 & {$[26]$} \\
\hline & & 905.50 & 61.97 & [28] \\
\hline & & 907.46 & 60.95 & This work \\
\hline \multirow{5}{*}{$\mathrm{L} \leftrightarrow \mathrm{Al}_{2} \mathrm{Ca}$} & \multirow{5}{*}{ Congruent } & $1,352.00$ & 33.30 & [24] \\
\hline & & $1,359.00$ & - & [25] \\
\hline & & $1,359.60$ & 33.30 & [26] \\
\hline & & $1,354.00$ & 33.33 & [28] \\
\hline & & $1,359.10$ & 33.33 & This work \\
\hline \multirow{4}{*}{$\mathrm{L} \leftrightarrow \mathrm{Al}_{3} \mathrm{Ca}_{8}$} & \multirow{4}{*}{ Congruent } & 852.00 & - & [24] \\
\hline & & 853.40 & 72.70 & [26] \\
\hline & & 852.00 & 72.72 & [28] \\
\hline & & 852.43 & 72.72 & This work \\
\hline
\end{tabular}

good agreement between the calculated values and the results of Schürmann et al. [33] and Jacob et al. [32] as shown in Figure 8 . The calculated activity of $\mathrm{Al}$ agrees fairly well with Sommer et al. [30].

The calculated thermodynamic properties for the four intermetallic compounds are compared with other data from the literature in Table V. The thermodynamic properties of enthalpy, entropy and Gibbs energy of formation of $\mathrm{Al}_{2} \mathrm{Ca}$ and $\mathrm{Al}_{4} \mathrm{Ca}$ obtained in this study agree very well with the most recent experimental results from the literature $[26,34,35]$. The existence of the two intermetallic compounds $\mathrm{Al}_{3} \mathrm{Ca}_{8}$ and $\mathrm{Al}_{14} \mathrm{Ca}_{13}$ is indicated only in recent studies [25,27] and few experimental values for their thermodynamic properties are reported in the literature. The enthalpy and Gibbs energy of 
Table V - Thermodynamic properties of different stoichiometric compounds in the Al-Ca system with experimental data from the literature

\begin{tabular}{|c|c|c|c|c|c|}
\hline Compound & $\begin{array}{l}\text { Method } \\
\text { [Ref] }\end{array}$ & $\mathrm{T}(\mathrm{K})$ & $\begin{array}{c}\Delta_{\mathrm{f}} \mathrm{H} \\
\mathrm{kJ} / \mathrm{g} \text {-atom }\end{array}$ & $\begin{array}{c}\Delta_{\mathrm{f}} \mathrm{S} \\
\mathrm{J} / \mathrm{g} \text {-atom.K }\end{array}$ & $\begin{array}{c}\Delta_{\mathrm{f}} \mathrm{G} \\
\mathrm{kJ} / \mathrm{g} \text {-atom }\end{array}$ \\
\hline \multirow{6}{*}{$\mathrm{Al}_{2} \mathrm{Ca}$} & HT [34] & 673-903 & $-31.28 \pm 0.46$ & $-5.67 \pm 0.93$ & \\
\hline & PC [31] & 1038 & $-33.40 \pm 0.60$ & & \\
\hline & Emf [35] & 800 & $-34.30 \pm 3.50$ & $-6.10 \pm 1.10$ & $-28.30 \pm 0.30$ \\
\hline & DC [26] & 298 & $-29.40 \pm 0.90$ & & \\
\hline & A [26] & 800 & -29.70 & -5.02 & -25.70 \\
\hline & $\mathrm{Cal}^{*}$ & 298 & -29.28 & -5.38 & -27.70 \\
\hline \multirow{5}{*}{$\mathrm{Al}_{4} \mathrm{Ca}$} & HT [34] & $673-903$ & $-20.18 \pm 0.38$ & $-4.29 \pm 0.78$ & \\
\hline & PC [31] & 1038 & $-18.70 \pm 0.30$ & & \\
\hline & Emf [35] & 800 & $-19.40 \pm 3.30$ & $-1.10 \pm 0.50$ & $-17.80 \pm 0.14$ \\
\hline & A [26] & 800 & -21.00 & -5.49 & -16.60 \\
\hline & $\mathrm{Cal}^{*}$ & 298 & -17.27 & -2.24 & -16.60 \\
\hline \multirow{3}{*}{$\mathrm{Al}_{3} \mathrm{Ca}_{8}$} & $\mathrm{DC}[26]$ & 298 & $-13.70 \pm 1.30$ & & \\
\hline & A [26] & 800 & -14.00 & -0.47 & -13.60 \\
\hline & $\mathrm{Cal}^{*}$ & 298 & -15.63 & -2.30 & -14.94 \\
\hline \multirow{2}{*}{$\mathrm{Al}_{14} \mathrm{Ca}_{13}$} & $\mathrm{~A}[26] \mathrm{AlCa}$ & 800 & -22.80 & -2.15 & -21.10 \\
\hline & $\mathrm{Cal} * \mathrm{Al}_{14} \mathrm{Ca}_{13}$ & 298 & -26.06 & -5.63 & -24.38 \\
\hline
\end{tabular}

HT : Hydrogen Titration, PC: Precipitation Calorimetry, DC: Dissolution Calorimetry A: Assessed, Cal*: Calculated in this work. As temperature does not have any effect on the enthalpy and entropy of the formation of stoichiometric compounds, the calculated values are compared with the values reported at different temperatures.

formation of $\mathrm{Al}_{3} \mathrm{Ca}_{8}$ compound agree fairly well with the results from the literature [26], whereas, the thermodynamic properties for $\mathrm{Al}_{14} \mathrm{Ca}_{13}$ are not available in the literature yet. Hence, the calculated thermodynamic properties for this compound were compared with the properties of $\mathrm{AlCa}$ in Table V. Nevertheless, it was noticed that the thermodynamic properties of these two compounds are very close.

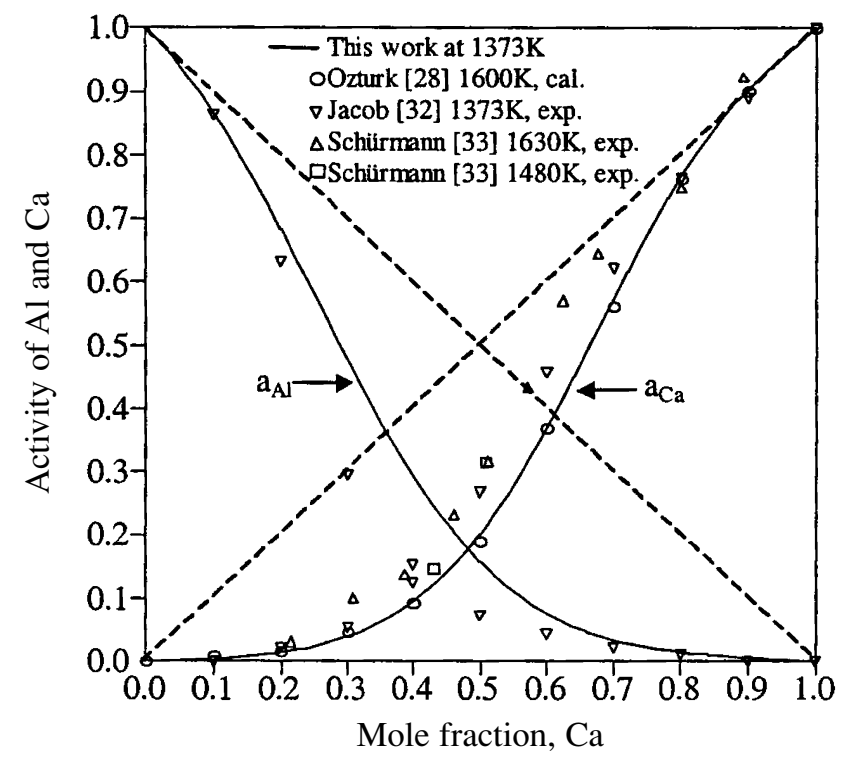

Fig. 8. Activity of $\mathrm{Al}$ and $\mathrm{Ca}$ in $\mathrm{Al}-\mathrm{Ca}$ liquid (cal.: calculated, exp.: experimental).
The enthalpy of formation of the four stoichiometric compounds from the previous experimental results and present calculated values are shown in Figure 9. It can be seen that the results obtained in this study agree with those from the literature. The difference obtained for $\mathrm{Al}_{14} \mathrm{Ca}_{13}$ is due to the fact that Kevorkov et al. [26] considered this compound as $\mathrm{AlCa}$ as discussed earlier.

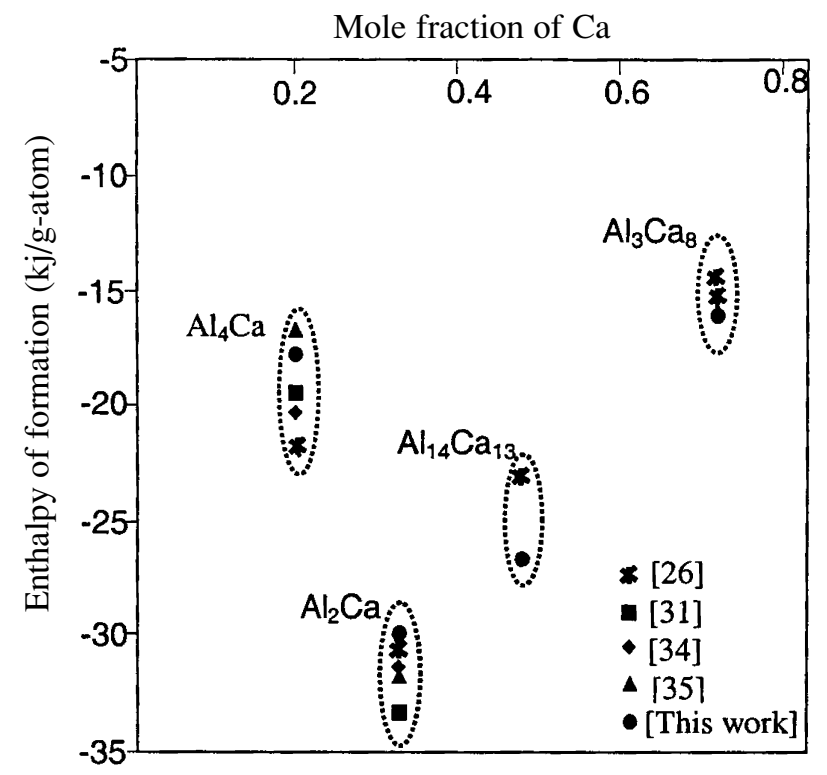

Fig. 9. Enthalpy of formation of different stoichiometric compounds in the Al-Ca system. 


\section{Mg-Al SYSTEM}

The Mg-Al system has already been optimized. The optimized parameters for this system were taken from COST 507 database [36] because this is the most recent and reliable database. More importantly, this is consistent with the thermodynamic description of the other two binary systems.

\section{Mg-Al-Ca SYSTEM}

\section{Phase Diagram}

Prince [37] mentioned that Portnoi and Spektorova first published preliminary work on the Mg-Al-Ca system in 1948. They reported a pseudobinary section $\mathrm{Mg}-\mathrm{Al}_{2} \mathrm{Ca}$ with a eutectic liquid composition of about 79 at\% Mg. They also report-

Table VI - Calculated invariant points of the Mg-Al-Ca system based on mole fraction

\begin{tabular}{|c|c|c|c|c|c|}
\hline \multirow{2}{*}{ Reaction / reaction type } & \multirow{2}{*}{$\begin{array}{l}\text { Temp } \\
(\mathrm{K})\end{array}$} & \multicolumn{3}{|c|}{ Mole fraction } & \multirow[t]{2}{*}{ Reference } \\
\hline & & $\mathrm{Ca}$ & $\mathrm{Mg}$ & $\mathrm{Al}$ & \\
\hline \multirow{3}{*}{$\begin{array}{l}\mathrm{L} \leftrightarrow \mathrm{Mg}_{2} \mathrm{Ca}+\mathrm{Ca}-\mathrm{fcc}+\mathrm{Al}_{3} \mathrm{Ca}_{8} / \\
\text { eutectic } \mathrm{E}_{1}\end{array}$} & 710.54 & 0.716 & 0.252 & 0.032 & \multirow{3}{*}{$\begin{array}{c}\text { This work } \\
{[5]} \\
{[40]}\end{array}$} \\
\hline & 683.00 & 0.680 & 0.190 & 0.130 & \\
\hline & 703.10 & 0.719 & 0.232 & 0.049 & \\
\hline \multirow{3}{*}{$\begin{array}{l}\mathrm{L} \leftrightarrow \mathrm{Mg}_{2} \mathrm{Ca}+\mathrm{Al}_{3} \mathrm{Ca}_{8}+\mathrm{Al}_{14} \mathrm{Ca}_{13} / \\
\text { eutectic } \mathrm{E}_{2}\end{array}$} & 764.19 & 0.612 & 0.133 & 0.255 & \multirow{3}{*}{$\begin{array}{c}\text { This work } \\
{[5]} \\
{[40]}\end{array}$} \\
\hline & 761.00 & 0.640 & 0.080 & 0.280 & \\
\hline & 769.40 & 0.612 & 0.153 & 0.235 & \\
\hline \multirow{3}{*}{$\begin{array}{l}\mathrm{L} \leftrightarrow \mathrm{Mg}_{2} \mathrm{Ca}+\mathrm{Al}_{2} \mathrm{Ca}+(\mathrm{Mg}) / \\
\text { eutectic } \mathrm{E}_{3}\end{array}$} & 754.72 & 0.109 & 0.799 & 0.092 & \multirow{3}{*}{$\begin{array}{c}\text { This work } \\
{[37]} \\
{[40]}\end{array}$} \\
\hline & 783.00 & 0.120 & 0.790 & 0.090 & \\
\hline & 770.20 & 0.110 & 0.840 & 0.050 & \\
\hline \multirow{3}{*}{$\mathrm{L} \leftrightarrow \gamma+\mathrm{Al}_{2} \mathrm{Ca}+(\mathrm{Mg}) /$ eutectic $\mathrm{E}_{4}$} & 701.50 & 0.012 & 0.672 & 0.316 & \multirow{3}{*}{$\begin{array}{c}\text { This work } \\
{[5]} \\
{[40]}\end{array}$} \\
\hline & 697.00 & 0.020 & 0.650 & 0.330 & \\
\hline & 706.40 & 0.005 & 0.682 & 0.313 & \\
\hline $\mathrm{L} \leftrightarrow \mathrm{Al}_{2} \mathrm{Ca}+\gamma+\beta /$ eutectic $\mathrm{E}_{5}$ & 715.92 & 0.011 & 0.412 & 0.577 & This work \\
\hline \multirow{3}{*}{$\mathrm{L} \leftrightarrow \mathrm{Al}_{4} \mathrm{Ca}+(\mathrm{Al})+\beta /$ eutectic $\mathrm{E}_{6}$} & 717.00 & 0.011 & 0.347 & 0.642 & \multirow{3}{*}{$\begin{array}{c}\text { This work } \\
{[5]} \\
{[40]}\end{array}$} \\
\hline & 715.00 & 0.020 & 0.340 & 0.640 & \\
\hline & 720.40 & 0.006 & 0.351 & 0.643 & \\
\hline \multirow{3}{*}{$\mathrm{L} \leftrightarrow \mathrm{Mg}_{2} \mathrm{Ca}+\mathrm{Al}_{3} \mathrm{Ca}_{8} /$ saddle $\mathrm{S}_{1}$} & 768.11 & 0.632 & 0.153 & 0.215 & \multirow{3}{*}{$\begin{array}{c}\text { This work } \\
{[5]} \\
{[40]} \\
\end{array}$} \\
\hline & 765.00 & 0.640 & 0.100 & 0.260 & \\
\hline & 771.80 & 0.627 & 0.173 & 0.200 & \\
\hline \multirow{3}{*}{$\mathrm{L} \leftrightarrow \mathrm{Mg}_{2} \mathrm{Ca}+\mathrm{Al}_{2} \mathrm{Ca} /$ saddle $\mathrm{S}_{2}$} & 902.96 & 0.337 & 0.456 & 0.207 & \multirow{3}{*}{$\begin{array}{c}\text { This work } \\
{[5]} \\
{[40]}\end{array}$} \\
\hline & $1,008.00$ & 0.360 & 0.230 & 0.410 & \\
\hline & 912.10 & 0.334 & 0.496 & 0.170 & \\
\hline \multirow{7}{*}{$\mathrm{L} \leftrightarrow \mathrm{Al}_{2} \mathrm{Ca}+(\mathrm{Mg}) /$ saddle $\mathrm{S}_{3}$} & 773.88 & 0.075 & 0.778 & 0.147 & \multirow{3}{*}{$\begin{array}{c}\text { This work } \\
\text { [5] }\end{array}$} \\
\hline & 808.00 & - & $0.780-$ & - & \\
\hline & - & $\begin{array}{l}0.790 \\
-\end{array}$ & 0.790 & - & \\
\hline & - & $0.740-$ & $\begin{array}{c}0.190 \\
-\end{array}$ & {$[37]$} & ] \\
\hline & & 0.830 & & & \\
\hline & 808.00 & - & - & - & [38] \\
\hline & 815.00 & 0.054 & 0.832 & 0.114 & {$[40]$} \\
\hline \multirow{3}{*}{$\mathrm{L} \leftrightarrow \mathrm{Al}_{2} \mathrm{Ca}+\gamma /$ saddle $\mathrm{S}_{4}$} & 723.80 & 0.013 & 0.565 & 0.423 & \multirow{3}{*}{$\begin{array}{c}\text { This work } \\
{[5]} \\
{[40]}\end{array}$} \\
\hline & 717.00 & 0.030 & 0.490 & 0.480 & \\
\hline & 732.50 & 0.006 & 0.541 & 0.453 & \\
\hline $\mathrm{L} \leftrightarrow \mathrm{Al}_{2} \mathrm{Ca}+\beta /$ Saddle $\mathrm{S}_{5}$ & 718.37 & 0.015 & 0.372 & 0.613 & This work \\
\hline \multirow{3}{*}{$\begin{array}{l}\mathrm{L}+\mathrm{Al}_{2} \mathrm{Ca} \leftrightarrow \mathrm{Al}_{14} \mathrm{Ca}_{13}+\mathrm{Mg}_{2} \mathrm{Ca} / \\
\text { ternary quasiperitectic } \mathrm{P}_{1}\end{array}$} & 823.89 & 0.539 & 0.184 & 0.277 & \multirow{3}{*}{$\begin{array}{c}\text { This work } \\
{[5]} \\
{[40]}\end{array}$} \\
\hline & 757.00 & 0.580 & 0.130 & 0.290 & \\
\hline & 829.20 & 0.542 & 0.195 & 0.263 & \\
\hline $\begin{array}{l}\mathrm{L}+\mathrm{Al}_{2} \mathrm{Ca} \leftrightarrow \mathrm{Al}_{4} \mathrm{Ca}+\beta / \\
\quad \text { ternary quasiperitectic } \mathrm{P}_{2}\end{array}$ & 717.39 & 0.011 & 0.356 & 0.633 & This work \\
\hline
\end{tabular}


ed a ternary eutectic point at about 9 at\% $\mathrm{Al}$ and 79 at\% $\mathrm{Mg}$. In 1959 the Dow Chemical Company confirmed the eutectic nature of the $\mathrm{Mg}-\mathrm{Al}_{2} \mathrm{Ca}$ section and placed the eutectic composition between 74 and 83 at $\% \mathrm{Mg}$. According to Prince [37], a partial isothermal section of the Mg-rich corner at 563, 643 and $723 \mathrm{~K}$ was reported by Catterall and Pleasance in 1957 and in 1958, Stacey recognized the possibility of a solid solution of $\mathrm{Mg}$ in $\mathrm{Al}_{2} \mathrm{Ca}$ instead of a separate ternary phase.

Gröbner et al. [5] investigated the phase equilibria of the Mg-Al-Ca system experimentally. They reported several invariant reactions in the ternary $\mathrm{Mg}$-Al-Ca system. Two peritectic reactions, one eutectic reaction and two saddle points were confirmed by experimental data. Large ternary solubilities for three binary phases $\mathrm{Mg}_{2} \mathrm{Ca}, \mathrm{Al}_{2} \mathrm{Ca}$ and $\mathrm{Al}_{3} \mathrm{Ca}_{8}$ were reported in their work.

At the same time, Tkachenko et al. [38] published their experimental work on this system. They studied the phase equilibira in the composition range of 50 to $100 \mathrm{wt} \% \mathrm{Mg}$ and reported an isothermal section at $150{ }^{\circ} \mathrm{C}$, the liquidus projection on Mg-rich corner and vertical section at 4.5, 8.5 and $16 \mathrm{wt} \% \mathrm{Al}$. They determined the peritectic transformation $\mathrm{Lp}+\mathrm{Al}_{2} \mathrm{Ca}(\mathrm{Mg})+\mathrm{Mg}_{17} \mathrm{Al}_{12}$ that occurs at $470{ }^{\circ} \mathrm{C}$.

On the other hand, Ozturk et al. [39] performed experimental work to verify the thermodynamic database developed for the Mg-Al-Ca system. During their study, the experimental work was still underway. Due to a lack of experimental data, they did not consider the solubility of the binary compounds and no ternary interactions were introduced either. Hence, the thermodynamic description of the $\mathrm{Mg}-\mathrm{Al}-\mathrm{Ca}$ ternary system was obtained by combining the data of the three binary systems. They also calculated five isothermal sections at 298, 563, 643, 673 and $723 \mathrm{~K}$. There was a good agreement between the experimental and calculated values except for the extent of the $\mathrm{Mg}$ phase field at $643 \mathrm{~K}$ where the calculation predicted less $\mathrm{Ca} \%$ than the measured values.
They mentioned that this inconsistency might be due to the calcium loss during alloy preparation.

A detailed XRD and transmission electron microscopy (TEM) investigation by Luo [4] suggested the presence of a ternary solid solution phase. It was represented by the chemical formula of $(\mathrm{Mg}, \mathrm{Al})_{2} \mathrm{Ca}$. This is in agreement with the result of Ozturk et al. [39]. In fact, the metallurgical stability of the ternary $(\mathrm{Mg}, \mathrm{Al})_{2} \mathrm{Ca}$ phases and their interfacial coherency with the magnesium matrix were reported to be responsible for the improved creep resistance of $\mathrm{Mg}-\mathrm{Al}-\mathrm{Ca}$ alloys at temperatures up to $473 \mathrm{~K}$.

\section{Calculated Mg-Al-Ca Phase Diagram}

The ternary phase diagram was calculated by not considering any ternary interaction parameters. Ternary compounds were not included because of the uncertainty related with their existence, stability, homogeneity range and melting temperature. In this work the solid solubility between the binary compounds was not considered due to a lack of experimental data. Taking into consideration all the thermodynamic and phase equilibria data stated for the binary phases and SGTE data [6] for pure elements, the $\mathrm{Mg}-\mathrm{Ca}-\mathrm{Al}$ system was calculated.

\section{Liquidus Projection of Mg-Al-Ca System}

Isothermal sections are directly calculated from the database developed for this system. Prior to solidification at high temperatures (above $1360 \mathrm{~K}$ ), the whole concentration triangle is composed of a homogeneous liquid phase and obviously no phase boundaries exist. At $1300 \mathrm{~K}$, the primary crystallization of $\mathrm{Al}_{2} \mathrm{Ca}$ sets in but is still above the melting point of the three components. At $700 \mathrm{~K}$, no residual liquid phase was present. A two-dimensional representation of the ternary liquidus surface

Table VII - Thermodynamic analysis of three alloys in the Mg-Al-Ca system with DSC measurements from [41] and [42]

\begin{tabular}{|c|c|c|c|c|c|c|}
\hline \multirow{2}{*}{$\begin{array}{c}\text { Sample } \\
\#\end{array}$} & \multicolumn{3}{|c|}{ Composition (wt\%) } & \multirow{2}{*}{$\begin{array}{c}\text { DSC } \\
\text { thermal } \\
\text { signals }\left({ }^{\circ} \mathrm{C}\right)\end{array}$} & \multicolumn{2}{|c|}{$\begin{array}{l}\text { Thermodynamic prediction from } \\
\text { this work }\end{array}$} \\
\hline & $\mathrm{Ca}$ & $\mathrm{Mg}$ & $\mathrm{Al}$ & & Temp. $\left({ }^{\circ} \mathrm{C}\right)$ & Reactions \\
\hline 1 & 4.5 & 78 & 17.5 & $\begin{array}{l}555 \mathrm{~h} / 550 \mathrm{c} \\
443 \mathrm{~h} / 431 \mathrm{c}\end{array}$ & $\begin{array}{l}539 \\
485 \\
427\end{array}$ & $\begin{array}{l}\mathrm{L} /(\mathrm{Mg})+\mathrm{L} \\
(\mathrm{Mg})+\mathrm{L} / \mathrm{Al}_{2} \mathrm{Ca}+(\mathrm{Mg})+\mathrm{L} \\
\mathrm{Al}_{2} \mathrm{Ca}+(\mathrm{Mg})+\mathrm{L} / \\
(\mathrm{Mg})+\mathrm{Al}_{2} \mathrm{Ca}+\gamma\end{array}$ \\
\hline 2 & 23.4 & 44 & 32.6 & $\begin{array}{c}760 \mathrm{c} \\
535 \mathrm{~h} / 523 \mathrm{c} \\
472 / 443 \mathrm{c}\end{array}$ & $\begin{array}{r}742 \\
504 \\
170\end{array}$ & $\begin{array}{l}\mathrm{L} / \mathrm{L}+\mathrm{Al}_{2} \mathrm{Ca} \\
\mathrm{L}+\mathrm{Al}_{2} \mathrm{Ca} / \mathrm{Al}_{2} \mathrm{Ca}+(\mathrm{Mg}) \\
\mathrm{Al}_{2} \mathrm{Ca}+(\mathrm{Mg}) / \\
\mathrm{Al}_{2} \mathrm{Ca}+(\mathrm{Mg})+\gamma\end{array}$ \\
\hline 3 & 24.19 & 73.08 & 2.73 & $\begin{array}{c}445.37 \mathrm{c} \\
521.32 \mathrm{c} \\
570 \mathrm{c}\end{array}$ & $\begin{array}{l}480 \\
503 \\
600\end{array}$ & $\begin{array}{l}\mathrm{L} / \mathrm{L}+\mathrm{Mg}_{2} \mathrm{Ca} \\
\mathrm{L}+\mathrm{Mg}_{2} \mathrm{Ca} / \\
\mathrm{L}+\mathrm{Mg}_{2} \mathrm{Ca}+(\mathrm{Mg}) \\
\mathrm{L}+\mathrm{Mg}_{2} \mathrm{Ca}+(\mathrm{Mg}) / \\
\mathrm{Mg}_{2} \mathrm{Ca}+(\mathrm{Mg})+\mathrm{Al}_{2} \mathrm{Ca}\end{array}$ \\
\hline
\end{tabular}


may be obtained as an orthogonal projection of a liquidus line from isothermal sections at different temperatures upon the base composition triangle. Such polythermal projection of the liquidus of the Mg-Al-Ca system is shown in Figures 10 and 11 which are based on mole and weight fraction, respectively. The univariant valleys are shown as heavier lines. By convention, the large arrows indicate the directions of decreasing temperature along these lines. As solidification proceeds by the precipitation of primary phases, the composition of the liquid changes and this change is represented by a path on the liquidus projection, occurring in a direction representing a lowering of the temperature on the liquidus surface. Figures 10 and 11 show the six ternary eutectic $\left(\mathrm{E}_{1}\right.$ to $\left.\mathrm{E}_{6}\right)$ points, two ternary quasi peritectic points $\left(P_{1}\right.$ to $\left.P_{2}\right)$ and five saddle points $\left(S_{1}\right.$ to $\left.S_{5}\right)$. In the ternary phase diagram, $\mathrm{e}_{1}$ to $\mathrm{e}_{8}$ and $\mathrm{p}_{1}$ to $\mathrm{p}_{2}$ indicate the binary eutectic and peritectic points, respectively. Calculated ternary invariant points are listed in Table VI.

Recently, Parvez et al. [41] and Wang et al. [42] investigated the Mg-Al-Ca system experimentally using DSC and XRD techniques. For different samples, the DSC measurements and the calculated thermal arrests along with the phase field boundary are listed in Table VII. These experimental results are compared with thermodynamic calculations to confirm the phase transformation temperature and associated reactions. The vertical sections calculated using the database from this study are shown in Figure 12.

Figure 12 and Table VII show that the calculated liquidus temperature match well with the experimental results of [41] and [42]. However, there is some discrepancy between the calculated phase transformation temperatures and those reported in [41] and [42]. For instance, the transformation temperature predicted by thermodynamic modelling at 485 and $170^{\circ} \mathrm{C}$ for samples 1 and 2 , respectively were not observed in the DSC signals.

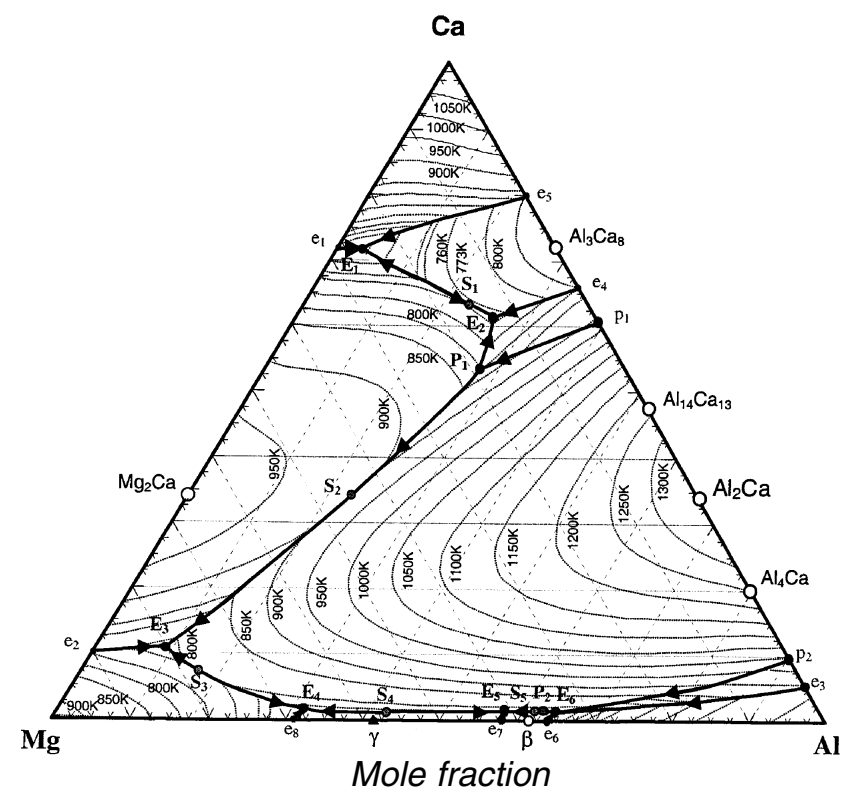

Fig. 10. Liquidus projection for the Mg-Al-Ca system based on mole fraction.

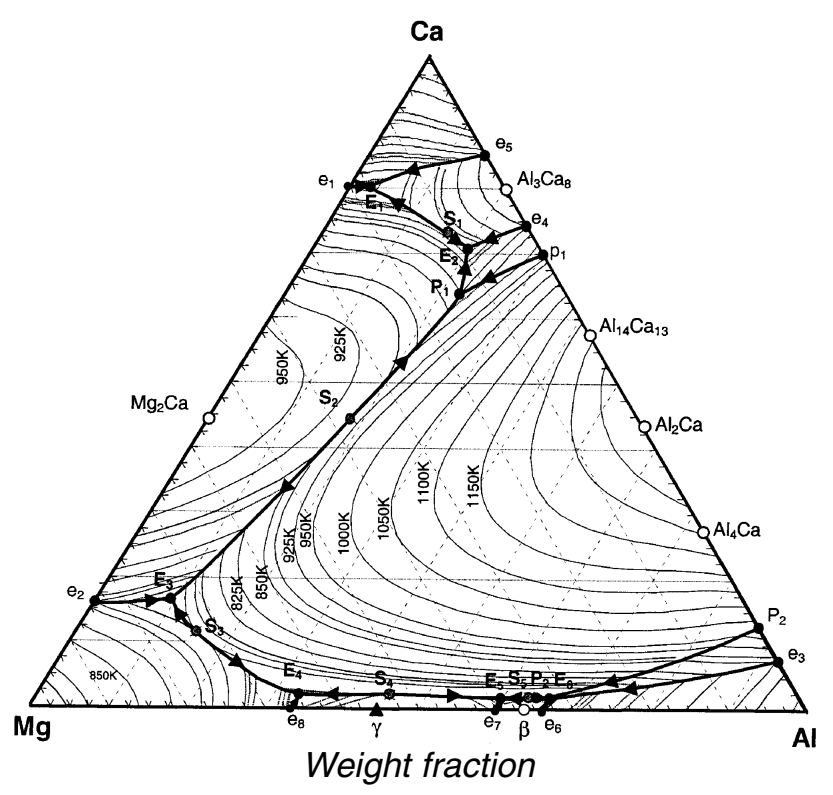

Fig. 11. Liquidus projection for the Mg-Al-Ca system based on weight fraction.

\section{SUMMARY}

In this research, $\mathrm{Mg}$-Al-Ca system was thermodynamically modeled and from the results, the following conclusions are drawn.

1. A minimum number of optimized thermodynamic coefficients was used to calculate the phase diagram and other integral and partial thermodynamic properties which were in good agreement with data reported in the literature. 2. A self-consistent thermodynamic description for the Mg-Al-Ca system was obtained.

3. The optimized model parameters can also be used to predict thermodynamic properties which are not available in the literature.

4. By combining model equations for the Gibbs energy of the phases of the three binary systems, the ternary $\mathrm{Mg}-\mathrm{Ca}-$ Al phase diagram was obtained. In this system, six ternary eutectic points in the temperature range of 701 to $764 \mathrm{~K}$, two peritectic points in the temperature range of 717 to $825 \mathrm{~K}$ and five saddle points in the temperature range of 724 to 904 $\mathrm{K}$ were found.

5. Vertical sections for different alloys were calculated and compared with the experimental data reported in the literature which confirmed the melting and the phase transformation temperatures satisfactorily.

\section{ACKNOWLEDGEMENTS}

The authors wish to acknowledge NSERC (Discovery Grant) and NATEQ (program Etablissement de nouveaux chercheurs) for partial financial support of this project. 

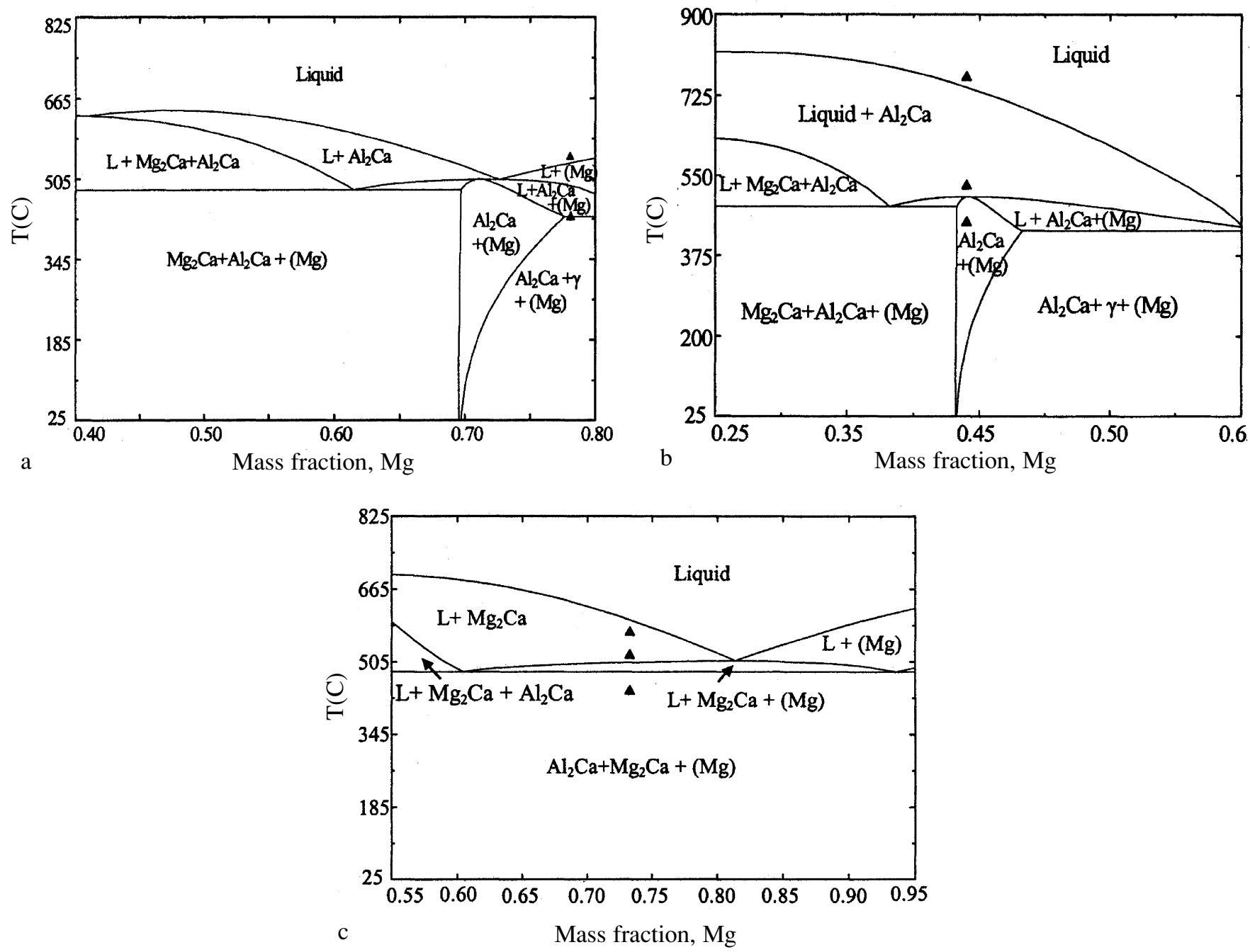

Fig. 12. Calculated vertical sections with experimental results from $[41,42]$ a) at constant $17.5 \mathrm{wt} \%$ Al with DSC signals of sample $1(4.5 / 78 / 17.5$ wt $\%$ $\mathrm{Ca} / \mathrm{Mg} / \mathrm{Al}), \mathrm{b})$ at constant $32.6 \mathrm{wt} \% \mathrm{Al}$ with DSC signals of sample $2(23.4 / 44 / 32.6 \mathrm{wt} \% \mathrm{Ca} / \mathrm{Mg} / \mathrm{Al})$ and c) at constant 2.73 wt $\% \mathrm{Al}$ with DSC signals of sample $3(24.19 / 73.08 / 2.73 \mathrm{wt} \% \mathrm{Ca} / \mathrm{Mg} / \mathrm{Al})$.

\section{REFERENCES}

1. Magnesium-alloys and Technologies, Willy-VCH, 2003, in German, 2003, U.K. Kainer, ed., pp. 1-7, 72-73, pp. 108-110.

2. P. Humble, "Toward a Cheap Creep Resistant Magnesium Alloy", Material Forum, 1997, vol. 21, pp. 45-56.

3. M.O. Pekguleryuz and J. Renaud, "Creep Resistance in $\mathrm{Mg}-\mathrm{Al}-\mathrm{Ca}$ Casting Alloys", Magnesium 2000 Symposium, TMS, 2000, pp. 279-84.

4. Z-K. Liu, "Understanding Magnesium Alloys Through Computational Thermodynamic", Magnesium 2000 Symposium, TMS, 2002, pp. 205-213.

5. J. Gröbner, D. Kevorkov, I. Chumak and R. Schmid-Fetzer, "Experimental Investigation and Thermodynamic Calculation of Ternary Al-Ca-Mg Phase Equilibria”, Z. Metallkd., 2003, vol. 94(9), pp. 976-982.

6. T. Dinsdale, "Thermodynamic Data of the Elements", CALPHAD, 1991, vol. 15 , pp. 317-425.

7. "WinPhaD - Phase Diagram Calculation Engine for Multicomponent Systems", Computherm LLC, 2000, Madison, WI, U.S.A.

8. "FactSage 5.2", Thermfact 2003, (Centre for Research in Computational Thermochemistry), Montreal, Quebec, Canada.
9. N. Baar, "On the Alloys of Molybdenum with Nickel, Manganese with Thallium and Calcium with Magneisum, Thallium, Lead, Copper and Silver", Z. Anorg. Allg. Chem., 1911, vol. 70, pp. 362-366.

10. R. Paris, "Contribution on the Ternary Alloys", Publ. Sci et Tech Ministére Air, 1934, vol. 45, France, pp. 39-41.

11. J.L. Haughton, "Alloys of Magnesium. Part 6-The Construction of the Magnesium-Rich Alloys of Magnesium and Calcium", J. Inst Met., 1937, vol. 61, pp. 241-246.

12. H. Vosskühler, "The Phase Diagram of Magnesium-Rich $\mathrm{Mg}-\mathrm{Ca}$ Alloys", Z. MetallKd, 1937, vol. 29, pp. 236-237.

13. W. Klemm and F. Dinkelacker, "On the Behavior of Magnesium with Calcium, Strontium and Barium", Z. Anorg. Chem., 1947, vol. 255, pp. 2-12.

14. A.A. Nayeb-Hashemi and J. B. Clark, "The Ca-Mg (Calcium-magnesium) System", Bull. Alloy Phase Diagrams, 1987, vol. 8, pp. 58-65.

15. R. Agarwal, J. Lee, H. Lukas and F. Sommer, "Calometric Measurements and Thermodynamic Optimization of the Ca-Mg System", Z. Metallkd., 1995, vol. 86(2), pp. 103-108.

16. E.C. Burke, "Solid Solubility of Calcium in Magnesium", Trnas. AIME, 1955 , vol. 203, pp. 285-286. 
17. R.C. King and O.J. Kleepaa, "A Thermodynamic Study of Some Selected Laves Phases", Acta Metall., 1964, vol. 12, pp. 87-97.

18. J.E. Davison and J.F. Smith, "Enthalpy of Formation of $\mathrm{CaMg}_{2}$ ", Trans. Met. Soc AIME, 1968, vol. 242, pp. 2045-2049.

19. F. Sommer, B. Predel and D. Assmann, "Thermodynamic Investigation of Liquid Alloys in the Systems $\mathrm{Mg}-\mathrm{Ca}, \mathrm{Mg}-\mathrm{Sr}$ and $\mathrm{Mg}-\mathrm{Ba}$ ", $\mathrm{Z}$. Metallkd., 1977, vol. 68(5), pp. 347-349.

20. R. Hultgren, P.D. Desai, D.T. Hawkins, M. Gleiser and K.K. Kelley, "Selected Values of the Thermodynamic Properties of Binary Alloys", Metal Park, 1973, p. 1435.

21. F. Sommer, "Thermodynamic Activities of Liquid Alloys in the System Ca-Mg Using a Modified Ruff Method", Z. MetallKd., 1979, vol. 70(8), pp. 545-547.

22. P.P. Mishra, M. Milanarun, N. Jha and A.K. Mishra, "Thermodynamic Properties of Liquid Glass-Forming Ca-Mg Alloys", J. Alloys Comp., 2002, vol. 340, pp. 108-113.

23. V.P. Mashovets and L. V. Puchkov, "Vapor Pressure over Molten Alloys in the System Mg-Ca", Zh. Prikl. Khim., 1965, vol. 38(5), pp. 10091014.

24. K. Matsuyama, "On the Equilibrium Diagram of the Al-Ca System", Sci. Reports Tohoku University, 1928, vol. 17, pp. 783-789.

25. D. Kevorkov and R. Schmid-Fetzer, "The Al-Ca System, Part 1: Experimental Investigation of Phase Equilibria and Crystal Structures", Z. Metallkde, 2001, vol. 92, pp. 946-952.

26. D. Kevorkov, R. Schmid-Fetzer, A. Pisch, F. Hodaj and C. Colinet, "The Al-Ca System, Part 2: Calorimetric Measurements and Thermodynamic Assessment", Z. Metallkde, 2001, vol. 92, pp. 953958.

27. B.Q. Huang and J.D. Corbett, "Two New Binary Calcium-Aluminum Compounds: $\mathrm{Ca}_{13} \mathrm{Al}_{14}$, with a Novel Two-Dimensional Aluminum Network and $\mathrm{Ca}_{8} \mathrm{Al}_{3}$ and $\mathrm{Fe}_{2} \mathrm{Al}$ Type Analogue", Inorganic Chem., 1998, vol. 27(22), pp. 5827-5833.

28. K. Ozturk, L-Q Chen and Z-K Liu, "Thermodynamic Assessment of the Al-Ca Binary System Using Random Solution and Associate Models", J. Alloys Comp., 2002, vol. 340, pp. 199-206.

29. V.P. Itkin, C.B. Alcock, P.J. Ekeren Van and H.A.J. Oonk, "The Al-Ca (Aluminum-Calcium) System”, Bull. Alloy Phase Diagrams, 1988, vol. 9, pp. 652-657.

30. F. Sommer, J.J. Lee and B. Predel, "Thermodynamic Investigations of Liquid Al-Ca, Al-Sr, Mg-Ni and Ca-Ni Alloys", Z. Metallkd, 1983, vol. 74(2), pp. 100-104.
31. M. Notin, J.C. Gachon and J. Hertz, "Enthalpy of Formation of $\mathrm{Al}_{4} \mathrm{Ca}$ and $\mathrm{Al}_{2} \mathrm{Ca}$ and of the Liquid Alloys (Aluminum+Calcium)", J. Chem. Thermodynamcis, 1982, vol. 14(5), pp. 425-434.

32. K.T. Jacob, S. Srikanth and Y. Waseda, "Activities, Concentration Fluctuations and Complexing in Liquid Ca-Al Alloys", Trans. Jpn. Inst. Met., 1988, vol. 29, pp. 50-59.

33. E. Schürmann, C.P. Fünders and H. Litterscheidt, "Vapor Presseure of Ca Above Ca-Si, Ca-Al and Ca-Al-Si Alloys", Arch. Eisenhuttenews., 1975, vol. 46, pp. 473-476.

34. E. Veleckis, "Application of the Hydrogen Titration Method to a Thermodynamic Investigation of Solid Al-Ca Alloys", J. Less-Common Met., 1981, vol. 80(2), pp. 241-255.

35. M. Notin, J. C. Gachon and J. Hertz, "Thermodynamic Data for Calcium-Based Alloys from a New Galvanic Method," CALPHAD, 1982, vol. 6(1), pp. 49-56.

36. I. Ansara, A.T. Dinsdale and M.H. Rand, "COST 507 Thermochemical Database for Light Metal Alloys", European Commission EUR 18499, 1998.

37. A. Prince, "Aluminum - Calcium - Magnesium", Ternary Alloys: A Comprehensive Compendium of Evaluated Constitutional Data and Phase Diagram, 1988, vol. 3, pp. 611-614.

38. V.G. Tkachenko, V.G. Khoruzhaya, K.A. Meleshevich, M.V. Karpets and V. V. Frizel, "Physicochemical and Structural Investigation of Materials", Powder Metal. Metal Ceramics, 2003, vol. 42, pp. 5-6.

39. K. Ozturk, Y. Zhong, A. Luo and Z-K Liu, "Creep Resistant Mg-Al-Ca Alloys: Computational Thermodynamics and Experimental Investigation", JOM, 2003, vol. 55(11), pp. 40-44.

40. K. Ozturk, "Investigation in Mg-Al-Ca-Sr System by Computational Thermodynamics Approach Coupled with First-Principles Energetics and Experiments", 2003, PhD thesis, Pennsylvania State University, U.S.A.

41. M.A. Parvez, X. Wang, E. Essadiqi and M. Medraj, "Experimental Investigation of the Equilibria in $\mathrm{Mg}-\mathrm{Al}-(\mathrm{Ca}, \mathrm{Sr})$ Systems", TMS, Magnesium Technology, 2005, pp. 179-185.

42. X. Wang, M.A. Parvez, E. Essadiqi and M. Medraj, "A Differential Scanning Calorimeter Study of Mg-Al-Ca Ternary System", CSME 2004 Forum, pp. 819-828. 
